\title{
Effects of Corona Virus (Covid-19) Pandemic On Small and Medium Scale Enterprises in Nigeria: A Case Study of Sango-Ota Industrial Estate
}

\author{
Amadi Chibuike Eusebius \\ Federal Polytechnic, Ede, Nigeria \\ Afolayan Olufunmilayo $T$. \\ The Federal Polytechnic, Ilaro, Nigeria \\ Aderemi Timothy Ayomitunde \\ Bells University of Technology, Ota, Nigeria \\ Onyeka Ndidi Camilia \\ Federal Polytechnic, Ede, Nigeria
}

Doi: 10.19044/elp.v7no4a1 URL:http://dx.doi.org/10.19044/elp.v7no4a1

\begin{abstract}
This survey was conducted to investigate the impact of COVID-19 lockdown on supply chain distribution and employment status of workers in small and medium enterprises engaging in three essential goods and services in Sango Ota, Nigeria. We collected data with the aid of a well-structured set of questionnaires, administered to SMEs engaging in three essentials- food and consumables, pharmaceuticals, oil, and gas operating in Sango-Ota industrial estate. Consequently, 45 SMEs, 30 SMEs, and 25 SMEs engaging in food and consumables, pharmaceuticals, oil, and gas respectively were purposively selected for this study. The findings that emerged in the work are as follows; COVID-19 lockdown did not disrupt to supply chain distribution of SMEs engaging in the three essential commodities in Sango Ota industrial estate. Also, no employee of the selected SMEs was laid off permanently due to the COVID-19 lockdown. But, SMEs engaging in both food and consumables, and oil and gas laid-off workers temporarily. Laying off workers temporarily might have been one of the spillovers of reduction in aggregate demand of products and services of the selected SMEs in their respective target markets due 'no movement order except those on essential duties`. Against this backdrop, the following recommendations are made for the policymakers in particular and all SMEs stakeholders in Nigeria in general that: coronavirus (COVID-19) lockdown is a threat to the survival of SMEs and job security of their employees in Nigeria as such the policymakers in Nigeria could reduce the vulnerability of these entities through emergency
\end{abstract}


funding or waiver of taxes to make them remain afloat during the lockdown and post lockdown period.

Keywords: COVID-19, Pandemic, SMEs, Essentials, Sango-Ota, Nigeria Classification JEL - M20, M21.

\section{Introduction}

In the field of entrepreneurship, studies focusing on small and medium scale enterprises (SMEs) are increasing across the globe in the recent time, due to the indispensable contributions of these ventures to nation-building (Aderemi et al. 2020; Aderemi et al. 2019; Tehseen and Ramayah, 2015). In a developing country like Nigeria, the important roles of small and medium scale enterprises (SMEs) cannot be undermined because they play active roles in the growth and the development of the country. For instance, it has been established that over $90 \%$ of existing businesses in Nigeria are small and medium businesses related (Oyelaran-Oyeyinka, 2020; Gbandi and Amissah, 2014). Therefore, these enterprises occupy the strategic part of the Nigerian economy in which proper research attention must not be ignored.

However, in early 2020, the novel coronavirus (COVID-19) which emerged in China, spread to the continent of Africa as one of the by-products of globalization (Aderemi et al., 2020). This virus has not only orchestrated dreadful havoc on human beings but also the economy across the globe. The diverse risks initiated by COVID-19 to all sectors of the economy are synonymous with that of the global financial crisis which left no country unaffected in 2008 (Dang and Nguyen, 2020). Meanwhile, an index case of the novel coronavirus (COVID-19) was recorded in Nigeria on February 27, 2020, through an Italian man who came into the country. Due to the fast rate at which this novel virus has spread and killed a lot of people in China, Italy, Spain, and the US (WHO, 2020). This motivated the Nigerian government to prevent the outbreak of this virus by shutting all national borders, worship centres, schools, and other non-essential activities on March 30, 2020. The epic centres of the virus in Nigeria- Lagos State, Ogun State, and the Federal Capital Territory (FCT) were the set of states that went on total lockdown for the first period of 14 days which later extended to May 3, 2020. During the period of lockdown, all non-essential businesses were closed and people were forced to stay at home.

Consequently, it is instructive to state that the closing of businesses would likely cause some negative effects on various economic variables in the economy. For example, the closure of business activities in Nigeria during the lockdown reverberated into loss of jobs and an increasing the crime rate in the country (Aifuwa, Musa \& Aifuwa, 2020). The total lockdown of the economy is more likely to pose dangers to the operations of small and medium scale 
enterprises in Nigeria since SMEs constitute $90 \%$ of business enterprises in Nigeria which engage over $70 \%$ of the Nigerian workforce (OyelaranOyeyinka, 2020). Against this backdrop, a study focusing on the impact of the novel coronavirus (COVID-19) on SMEs in Nigeria becomes very imperative at this time due to the strategic importance of SMEs in the country. To address the objective of this study, it is expected that the following specific research questions were raised

What are the effects of the COVID-19 pandemic on the workforce engaged in SMEs in Nigeria? What are the effects of COVID 19 on the supply chain of SMEs in Nigeria? Therefore, this study would contribute to knowledge by answering the above-raised research questions which no study has provided answers to in Nigeria.

\section{The objective of the Study}

The objective of the study is to examine the effects of COVID-19 pandemic on supply chain and the workforce of SMEs in Nigeria with evidence from Sango-Ota industrial Estate of Ogun state.

\section{Literature Review}

Studies regarding the extent to which the novel coronavirus has ravaged the economies across the globe are still ongoing. The major concern of various nations of the world is how to flatten the COVID-19 curve. However, in recent time, efforts have been made by scholars to account for the impact of this invisible enemy on the economies of the world. In the view of Ozili \& Arun (2020), the coronavirus pandemic had crumbled the Nigerian economy with the reverberation of hardship to its citizens. In another related study, Chen et al. (2018) argued that the severe acute respiratory syndrome (SARS) epidemic was the root cause of the reduction that existed between the stock exchange in China and four markets in Asia. This was discovered when the author was examining how the severe acute respiratory syndrome (SARS) epidemic affected the stock exchange market in China and four Asian economies.

Meanwhile, Aderemi et al. (2020) in their recent works which focused on the effect of the coronavirus (COVID-19) and globalization regarding the relationship between Africa and China. The authors posited that the coronavirus moved to Africa as a bad side of globalization. In another perspective, Chen, Jang, and Kim (2007) investigated the aftermath effect of SARS epidemic on the hotel industry in the economy of Taiwan. It was revealed from the study that the epidemic led to a negative total mean irregular of returns on stocks in the Taiwan hotel industry. Aderemi et al. (2020:2) assessed the impact of the coronavirus pandemic on small and medium enterprises in Nigeria. The authors submitted that COVID-19 lockdown led to 
a moderate reduction in the production and sales of the selected enterprises. Meanwhile, a spike in the reduction of contracts and deliveries was experienced by these enterprises during the lockdown. Also, Collins (2020) researched the contribution of the COVID-19 pandemic to the behavior of stock market value in the following economies; China, Europe, and the USA using a differential analysis technique. It was reported from the study that the COVID-19 pandemic orchestrated various dynamics in the stock markets of those selected economies. In another development, Ganale and Zafar (2020) evaluated how Coronavirus (COVID-19) affected small and medium enterprises (SMEs) in Pakistan. It was discovered from the study that the coronavirus pandemic stimulated a decline in operating activities of the firms, as well a disruption in supply chain and financial crisis in the sampled firms.

\section{Business Environment in Nigeria}

The relationship between business and its corresponding environment cannot be overemphasized, because the business does not operate in a vacuum. There is a need for a conducive environment for its survival. The environment in which business operates is domiciled in socio-economic, political, and cultural variables that determine the success or otherwise of the life, growth, and development of business enterprises.

However, in the case of the Nigerian economy, a harsh business climate has orchestrated many business ventures to pack up, stagger, collapse, and relocate from Nigeria Ogunro (2014). Although Nigeria is endowed with abundant resources, yet it lacks the required necessary infrastructure that could drive the economy through the proliferation of SMEs in the country. It is quite unfortunate that most critical infrastructures such as power (electricity) supply, roads, policies, and security of lives and properties are inadequate. This is driving the Nigerian economy backward, and thereby making the country`s business environment volatile and unsafe for investment. Against this backdrop, the Nigerian economy has been characterized with persistent rise in the unemployment rate, incidences of poverty on one hand and continuous dwindling in industries, industrial capacity utilization, the inflows of foreign direct investment (FDI), and underperformance of the non-oil sector on the other hand (Bello, 2011). 
Figure 1: Ease of Doing Business Index in Nigeria

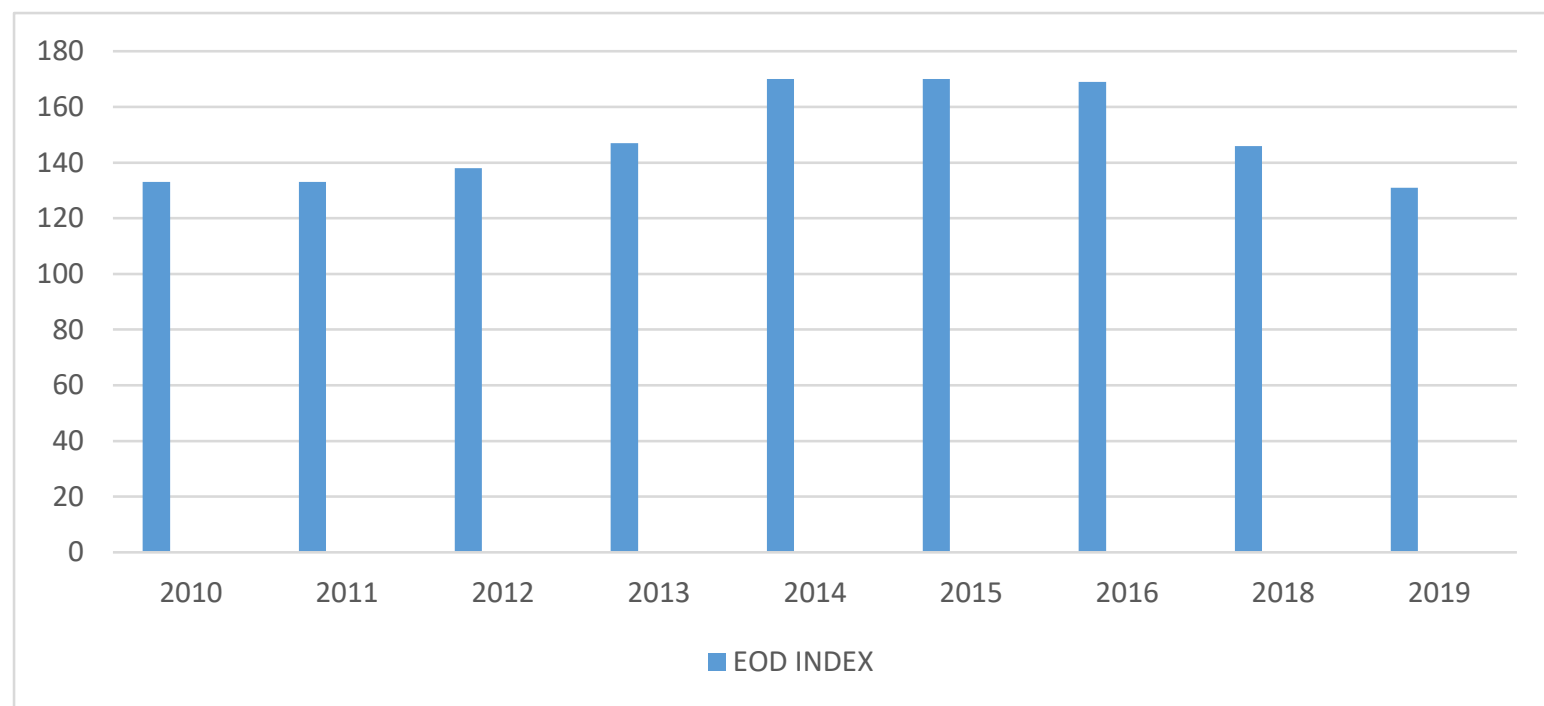

Source: Authors`Computation (2020) from Tradingeconomics.com

The figure above shows the trend of the ease of doing business index in Nigeria from 2010 to 2019. This index used some parameters to rank countries against each other. The parameters measures how the regulatory environment of countries is conducive vis-à-vis business operation and stronger protections of property rights. It is worth of note that, an economy which has a rank of 1 to 20 is said to possess simpler and more friendly regulations for businesses. Unfortunately, in the past last decade, the ease of doing business index in Nigeria has not been impressive. This might have been one of the critical factors responsible for the continuous dwindling in the inflows of foreign direct investment in Nigeria since 2012.

Furthermore, the National Bureau of Statistics (NBS) estimated the numbers of SMEs in Nigeria to be 41.4 million. There was a sharp decline in the number of medium-sized enterprises from 4,670 in 2013 to 1,793 in 2017. This implies that these enterprises decreased by $61 \%$ in Nigeria within a space of four years. This is a reflection of the unconducive business climate in the country. 


\section{Methodology and Estimation Study Design}

This study focuses on the aftermath effects of lockdown on operations of small and medium enterprises in Nigeria. In other to achieve this objective, the study includes the following studied variable as follows; sectoral distribution of the enterprises, the status of enterprises in terms of ownership structure, the target market of enterprises, operations of enterprises affected by a coronavirus. However, 100 SMEs that engage in essential goods and services were included in this study purposively. The motivation for using a purposive sampling technique in this work was largely due to the reason that only enterprises that engage in essential commodities and services were given the opportunity to carry out their normal routines during the lockdown. The SMEs that are involved in essentials entail food and consumables, pharmaceuticals, filling stations, and gas stations.

Meanwhile, a total of 100 SMEs were surveyed in the following order; 40 small and medium enterprises engaging in food and consumables, 30 small and medium enterprises in pharmaceuticals, and 30 small and medium enterprises involved in oil and gas businesses.

\section{The Study Area}

"Sango-Ota is a veritable industrial city in Ogun State, Nigeria, with an estimated population of 163,783 in the last 2006 census. Sango-Ota is the capital of the Ado-Odo Ota Local Government Area. The Local Government has the largest number of industries in the state. The local government contributes the highest internally generated revenues in Ogun state. Sango-Ota has one of the largest concentration of industries in Nigeria". Aderemi et al. (2020:2), P. 254. 


\section{Data Analysis and Presentation}

\section{Section 1: Background Information of the Selected SMEs}

Table 1: Classification of Essential Goods and Services

\begin{tabular}{|l|l|l|l|l|}
\hline Essentials & $\begin{array}{l}\text { Frequen } \\
\text { cy }\end{array}$ & $\begin{array}{l}\text { Percentage } \\
(\%)\end{array}$ & Valid \% & $\begin{array}{l}\text { Cumulative } \\
\%\end{array}$ \\
\hline $\begin{array}{l}\text { Food and } \\
\text { Consumables } \\
\text { Pharmaceuticals }\end{array}$ & 45 & 45 & 45 & 45 \\
$\begin{array}{l}\text { Oil and Gas } \\
\text { Total }\end{array}$ & 25 & 25 & 30 & 75 \\
& 100 & 100.0 & 100.0 & 100 \\
\hline
\end{tabular}

Source: Field Survey (2020)

The above table shows background information about the surveyed enterprises. It could be deduced that the enterprises engaging in food and consumables constitute the largest percentage (40\%) in the survey. This is followed by enterprises in pharmaceuticals and oil gas with $30 \%$ and $25 \%$ respectively.

Figure 2: Ownership Structure of the Enterprises

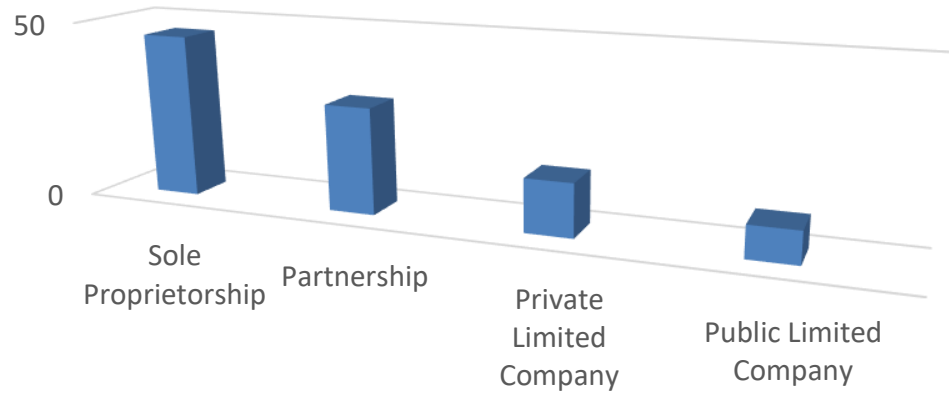

$\square$

Source: Field Survey (2020) 
In the above figure, the SMEs were classified in terms of the ownership structure. It is important to state that the majority of the selected SMEs are sole proprietorship, which occupies $46 \%$ of the sampled enterprises. Meanwhile, $30 \%$ of the SMEs is a partnership. Private limited companies and public limited companies are $15 \%$ and $9 \%$ respectively. The implication of this is that one man businesses are the majority of the participants in this study

\section{Figure 3: Classification of Enterprises (Annual Sales Turnover)}

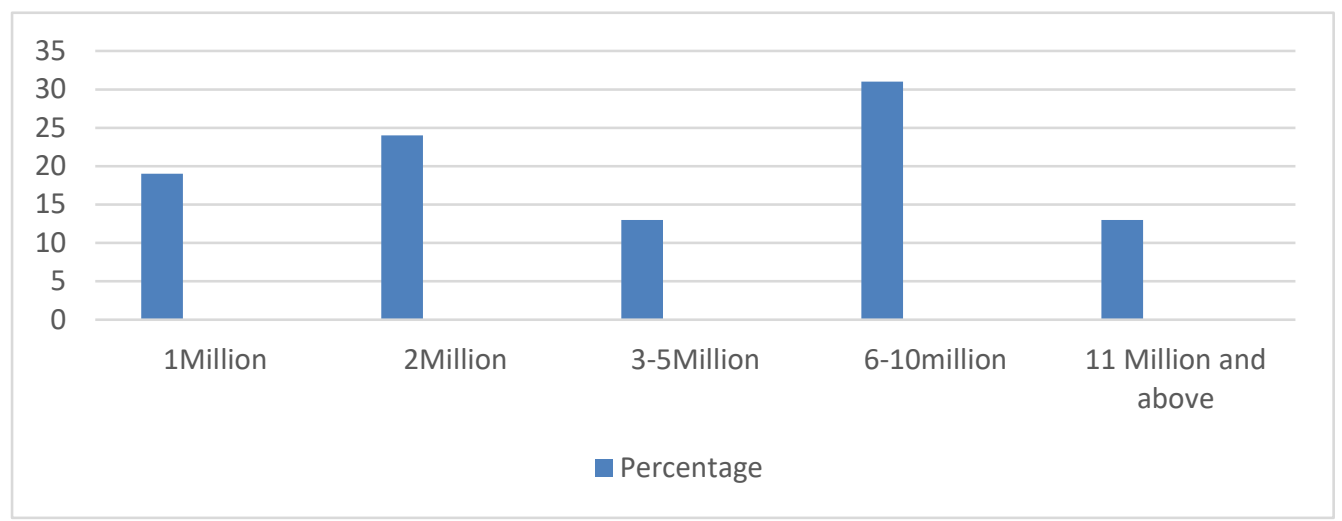

Source: Field Work (2020)

As shown in Table 2, the small and medium enterprises with 6-10 million annual turnover occupy about $32 \%$ of the survey. This is followed by SMEs with an annual turnover of 2 million, 1 million, which represents $24 \%$ and 19 of the selected sample respectively. Conversely, each of the SMEs with an annual turnover of 3-5 million occupies $13 \%$ of the survey. Therefore, the largest participants of the surveyed SMEs make a minimum of 3 million ad a maximum of 6 million as annual turnover.

Figure 4: Classification of Enterprises (Employment Size) 


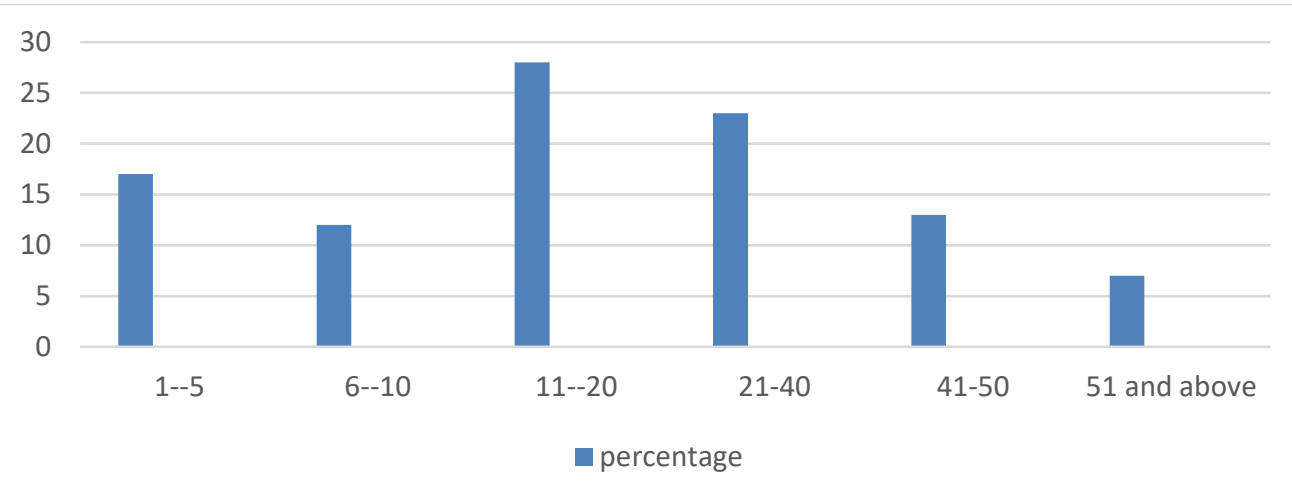

Source: Field Work (2020)

The employment capacity of the selected firms was shown in figure 4 . It could be deduced from the figure that $27 \%$ of the surveyed SMEs have a minimum of 11 workers and a maximum of 20 workers. $23 \%$ of the SMEs have a minimum of 21 workers and a maximum of 40 workers. In the same manner, $17 \%$ of the SMEs have a minimum of a worker and a maximum of 5 workers. $13 \%$ has a minimum of 40 workers and a maximum of 50 workers whereas $12 \%$ has a minimum of 6 workers and a maximum of 10 workers. $7 \%$ of the selected SMEs have a minimum of 51 workers. Therefore, most of the selected SMEs have a workforce that ranges from 11 employees to 40 employees.

\section{Figure 5: SMEs' Market (Within City, National Level or Export)}

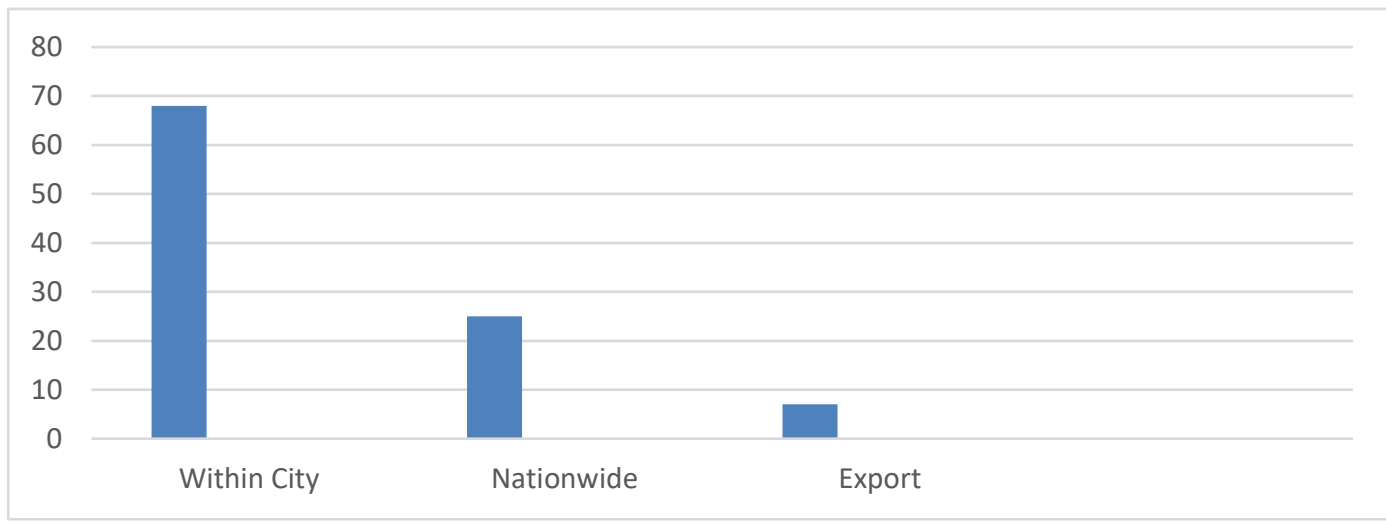

Source: Field Work (2020)

Figure 5 indicates the market coverage of the selected SMEs in this study. It is worthy of note that the majority of the SMEs target Sango Ota market and its environs for their sales and services as shown as reflected in the above figure, which shows 69\%. Similarly, 25\% of the SMEs target the entire country for the sales of their goods and services. Whereas, in extending the sales of goods and services beyond the borders of Nigeria, only $6 \%$ of the 
selected SMEs engage in such activities. The proximity of Sango Ota/ Idi Iroko to the Republic of Benin might have aided the extension of the sales of goods and services of some selected SMEs beyond the borders of Nigeria.

Section B: Operations of the SMEs Affected due to COVID-19 and Lock down

Table 2: Supply Chain Disruption in SMEs Engaging in Food and Consumables

\begin{tabular}{|l|l|l|l|l|}
\hline $\begin{array}{l}\text { Food and } \\
\text { Consumables }\end{array}$ & Frequency & $\begin{array}{l}\text { Percentage } \\
(\%)\end{array}$ & $\begin{array}{l}\text { Valid } \\
(\%)\end{array}$ & $\begin{array}{l}\text { Cumulative } \\
(\%)\end{array}$ \\
\hline Not at all & 11 & 24 & 24 & 24 \\
To a slight extent & 20 & 44 & 44 & 68 \\
To a moderate & 3 & 7 & 7 & 75 \\
extent & 4 & 9 & 9 & 84 \\
To a considerable & 4 & 9 & 9 & 93 \\
extent axtreme & 3 & 7 & 7 & 100 \\
To great extent & 45 & 100 & 100 & \\
To an extrem \\
extent \\
Total & & & \\
\hline
\end{tabular}

Source; Field Work (2020)

Table 2 shows that 11(24\%) did not believe that COVID-19 lockdown caused a supply chain disruption of SMEs engaging in food and consumables. Meanwhile, 20(44\%) believed that COVID 19 lockdown caused a slight disruption of supply chain distribution, 3(7\%) believed to a moderate extent, $4(9 \%)$ each to a considerate extent and a great extent respectively. Whereas $3(7 \%)$ believed COVID-19 lockdown caused an extreme disruption to the supply chain. This means that COVID-19 lockdown did not cause disruption to supply chain distribution of SMEs engaging in food and consumables in Sango Ota industrial suburb of Ogun State, Nigeria. 
Table 3: Supply Chain Disruption in SMEs Engaging in Pharmaceuticals

\begin{tabular}{|l|l|l|l|l|}
\hline Pharmaceuticals & $\begin{array}{l}\text { Frequenc } \\
\mathrm{y}\end{array}$ & $\begin{array}{l}\text { Percentage } \\
(\%)\end{array}$ & $\begin{array}{l}\text { Valid } \\
\%\end{array}$ & $\begin{array}{l}\text { Cumulati } \\
\text { ve \% }\end{array}$ \\
\hline $\begin{array}{l}\text { Not at all } \\
\text { To a slight extent }\end{array}$ & 14 & 46 & 46 & 46 \\
To a moderate extent & 3 & 37 & 37 & 83 \\
To a considerable & 2 & 10 & 10 & 93 \\
extent & 0 & 7 & 7 & 100 \\
To a great extent & 0 & 0 & 0 & 100 \\
To an extreme extent & 30 & 100 & 0 & 100 \\
Total & & & 100 & \\
& & & & \\
\hline
\end{tabular}

\section{Source: Field Work (2020)}

Table 3 shows that 14(46\%) did not believe COVID-19 lockdown caused a supply chain disruption of SMEs engaging in pharmaceuticals. However, 11(37\%) agreed that COVID 19 lockdown caused a slight disruption of supply chain distribution, $3(10 \%)$ believed to a moderate extent, $2(7 \%)$ to a considerate extent. Nobody submitted that the COVID-19 lockdown caused a great and extreme disruption to the supply chain in pharmaceuticals. This implies that COVID-19 lockdown did not cause any disruption to supply chain distribution of SMEs engaging in pharmaceuticals in Sango Ota industrial suburb of Ogun State, Nigeria.

Table 4: Supply Chain Disruption in SMEs Engaging in Oil and Gas

\begin{tabular}{|l|l|l|l|l|}
\hline Oil and Gas & Frequency & $\begin{array}{l}\text { Percentage } \\
(\%)\end{array}$ & Valid (\%) & $\begin{array}{l}\text { Cumulative } \\
(\%)\end{array}$ \\
\hline Not at all & 21 & 84 & 84 & 84 \\
To a slight extent & 4 & 16 & 16 & 100 \\
To a moderate extent & 0 & 0 & 0 & 100 \\
& 0 & 0 & 0 & 100 \\
\hline
\end{tabular}




\begin{tabular}{|l|l|l|l|l|}
\hline $\begin{array}{l}\text { To a considerable } \\
\text { extent }\end{array}$ & 0 & 0 & 0 & 100 \\
$\begin{array}{c}\text { To a great extent } \\
\text { To an extreme extent } \\
\text { Total }\end{array}$ & 25 & 0 & 0 & 100 \\
\hline
\end{tabular}

Source: Field Work (2020)

Table 4 shows that 21(84\%) did not submit that COVID-19 lockdown caused a supply chain disruption of SMEs engaging in oil and gas. Conversely, 4(16\%) agreed that COVID 19 lockdown caused a slight disruption of supply chain distribution. Meanwhile, when it comes to a moderate, considerate, great, and extreme disruption to the supply chain, no participant of SMEs in oil and gas subscribed to those. Therefore, the implication of this is that COVID-19 lockdown did not cause any disruption to supply chain distribution of SMEs engaging in oil and gas in Sango Ota industrial suburb of Ogun State, Nigeria.

Table 5: Employees Laid off by SMEs Engaging in Food and Consumables

\begin{tabular}{|c|c|c|c|c|}
\hline Employees Status & $\begin{array}{l}\text { Frequ } \\
\text { ency }\end{array}$ & $\begin{array}{l}\text { Percentage } \\
(\%)\end{array}$ & Valid \% & $\begin{array}{l}\text { Cumulative } \\
\%\end{array}$ \\
\hline $\begin{array}{ll}\text { Workers laid off } \\
\text { temporarily } \\
\text { Workers laid off } \\
\text { permanently } \\
\text { No workers laid off } & \\
\end{array}$ & $\begin{array}{l}21 \\
0 \\
383 \\
404\end{array}$ & $\begin{array}{l}5.2 \\
0 \\
94.8 \\
100\end{array}$ & $\begin{array}{l}5.2 \\
0 \\
94.8 \\
100\end{array}$ & $\begin{array}{l}5.2 \\
5.2 \\
100\end{array}$ \\
\hline
\end{tabular}

Source: Field Work (2020)

From table 5, it could be inferred that no worker was laid off permanently in SMEs engaging in food and consumables due to COVID-19 lockdown. However, 21(5\%) of the workers were laid off temporarily due to COVID-19 lockdown. Laying off workers temporarily might have been one of the spillovers of reduction in aggregate demand in the target market of the selected SMEs. 
Table 6: Employees Laid off by SMEs Engaging in Pharmaceutical Enterprises

\begin{tabular}{|c|c|c|c|c|}
\hline Employees Status & Frequency & $\begin{array}{l}\text { Percentage } \\
(\%)\end{array}$ & $\begin{array}{l}\text { Valid } \\
\%\end{array}$ & $\begin{array}{l}\text { Cumulative } \\
\%\end{array}$ \\
\hline $\begin{array}{l}\text { Workers laid off } \\
\text { temporarily laid off } \\
\text { Workers laid } \\
\text { permanently } \\
\text { No workers laid off } \\
\text { Total }\end{array}$ & $\begin{array}{l}0 \\
0 \\
73 \\
73\end{array}$ & $\begin{array}{l}10 \\
0 \\
90 \\
100\end{array}$ & $\begin{array}{l}10 \\
0 \\
90 \\
100\end{array}$ & $\begin{array}{l}10 \\
10 \\
100\end{array}$ \\
\hline
\end{tabular}

Source: Field Work (2020)

In table 6, no worker was laid off either temporarily or permanently in SMEs engaging in pharmaceuticals. This reason for this might have been the high necessity of pharmaceutical products and services in the fight against pandemics such as coronavirus.

Table 7: Employees Laid off by SMEs Engaging in Oil and Gas Enterprises

\begin{tabular}{|c|c|c|c|c|}
\hline Employees Status & Frequency & $\begin{array}{l}\text { Percentage } \\
(\%)\end{array}$ & Valid $\%$ & $\begin{array}{l}\text { Cumulative } \\
\%\end{array}$ \\
\hline $\begin{array}{l}\text { Workers laid off } \\
\text { temporarily } \\
\text { Workers laid off } \\
\text { permanently } \\
\text { No workers laid } \\
\text { off } \\
\text { Total }\end{array}$ & $\begin{array}{l}99 \\
0 \\
227 \\
326\end{array}$ & \begin{tabular}{|l}
30.4 \\
0 \\
69.6 \\
100
\end{tabular} & $\begin{array}{l}30.4 \\
0 \\
69.6 \\
100\end{array}$ & $\begin{array}{l}30.4 \\
30.4 \\
100\end{array}$ \\
\hline
\end{tabular}

Source: Field Work (2020)

From table 7, it was submitted that 99(30.4\%) of the workforce was laid off temporarily, though no worker was laid off permanently by SMEs engaging in oil and gas. Consequently, it is instructive to state that there was a significant percentage of workers laid off temporarily in oil and gas, this might have been the result of no movement order except those on essential duties in the country. This would cause a significant reduction in the demand for oil and gas for vehicle and industrial consumption.

\section{Conclusions}


This survey was conducted to investigate the impact of COVID-19 lockdown on supply chain distribution and employment status of workers in small and medium enterprises engaging in three essential goods and services in Sango Ota, an industrial suburb of Ogun State, Nigeria. We collected data with the aid of a well-structured set of questionnaires, administered to SMEs engaging in these three essentials- food and consumables, pharmaceuticals, oil, and gas operating in Sango-Ota industrial estate. Consequently, 45 SMEs, 30 SMEs, and 25 SMEs engaging in food and consumables, pharmaceuticals, oil, and gas respectively were purposively selected for this study. After a thorough analysis of the data, the study concludes that COVID-19 lockdown did not disrupt to supply chain distribution of SMEs engaging in three essentials- food and consumables, pharmaceuticals, and oil and gas in Sango Ota industrial suburb of Ogun State, Nigeria. It was also discovered that no employee of the selected SMEs was laid off permanently due to COVID-19 lockdown. But, SMEs engaging in both food and consumables, and oil and gas laid-off workers temporarily. Laying off workers temporarily might have been one of the spillovers of reduction in aggregate demand of products and services of the selected SMEs in their respective target markets due 'no movement order` except those on essential duties in the country. Against this backdrop, the following recommendations are made for the policymakers in particular and all SMEs stakeholders in Nigeria in general that: coronavirus (COVID-19) lockdown is a threat to the survival of SMEs and job security of their employees in Nigeria as such the policymakers in Nigeria could reduce the vulnerability of these entities through emergency funding or waiver of taxes to make them remain afloat during the lockdown and post lockdown period.

\section{Limitation of the Study}

The limitation of this study lies in its coverage -Sango Ota industrial suburb of Ogun state, Nigeria. The coverage of only this area was largely due to restriction of movement and more importantly lack of funding. Therefore, there is a limitation in its generalization. However, the generalization of this work could be further increased and improved in Nigeria and Africa by extension, if FUNDED this study could be carried out in all Local Governments of Ogun state or all states in Nigeria and all countries in Africa. 


\section{References:}

1. Aderemi, T.A., Adeniran, A. A, Amusa, B.O. \& Ebere, C. E. (2020). Globalization and Corona Virus (COVID-19) Pandemic; the Vulnerability of Africa is the Opportunity of China.Arabian Journal of Business and Management Review, 9(2), 27-30.

2. Aderemi, T. A., Lucas, B. O., Okoh, J. I. \& Efunbajo, S. A. (2020). Impact of Corona Virus (COVID-19) Pandemic on Small and Medium Scale Enterprises (SMEs) in Nigeria: A Critical Case Study. ACTA Universitatis Danubius, 16(4), 251-261.

3. Aderemi, T.A., Tolulope, A. C., Adedayo, A. \& Arinola, B. L. (2019). Entrepreneurship Financing and Nation Building in Nigeria: Evidence from Agricultural Small and Medium Scale Enterprises. Management Studies and Economic Systems, 4(4), 315-330.

4. Aifuwa, H. O., Saidu, M \& Aifuwa, S. A. (2020). Coronavirus Pandemic Outbreak and Firms Performance in Nigeria. Retrieved from, https://www.researchgate.net/publication/341152

5. Bello, M. (2011). Strategies for Sustainable Business Environment in Nigeria. A Paper Presented at National Conference on Economic Transformation Agenda, held in Abuja, October 2011.

6. Chen, M. H.; Jang, S. S. \& Kim, W. G. (2007). The impact of the SARS outbreak on Taiwanese hotel stock performance: an event-study approach. International Journal of Hospitality Management, 26(1), 200-212.

7. Chen, M. P.; Lee, C. C.; Lin, Y. H. \& Chen, W. Y. (2018). Did the SARS epidemic weaken the integration of Asian stock markets? Evidence from smooth time-varying cointegration analysis. Economic research-Ekonomska istraživanja, 31(1), 908-926.

8. Collins C. N. (2020). Effect of COVID-19 Pandemic on Global Stock Market Values: A Differential Analysis. ACTA Universitatis Danubius. 16(2), 261-275. 
9. Ganale, M. A. \& Zafar, F. (2020). Impact of COVID-19 (Coronavirus) on Small and Medium Enterprises (SMEs) in Pakistan. Small and Medium Enterprises Development Authority (SMEDA). SMEDA Research Journal View project

10. Gbandi, E. C. and Amissah, G. (2014) Financing Options for Small and Medium Enterprises (SMEs) in Nigeria European Scientific Journal, 10(1), 23-34.

11. Dang, T. L. \& Nguyen, T. M. H. (2020). Liquidity risk and stock performance during the financial crisis. Research in International Business and Finance, 52,101-165, retrieved from https://doi.org/10.1016/j.ribaf.2019.101165, date: 01.20.2020.

12. Ogunro, V. O. (2014). Nigeria's Business Environment: Issues Challenges and Prospects. International Journal of Academic Research in Business and Social Sciences, 4(4); 132-138.

13. Oyelaran-Oyeyinka, B. (2020). SMEs Issues, challenges and prospect. Financial System Strategy

14. Ozili, P \& Arun, T. (2020). Spillover of COVID-19: Impact on the global economy. Retrieved from https://mpra.ub.unimuenchen.de/99850/

15. Tehseen, S. and Ramayah, T. (2015). Entrepreneurial Competencies and SMEs Business Success: The Contingent Role of External Integration. Mediterranean Journal of Social Sciences, 6(1), 50-61.

16. WHO. (2020). COVID-2019 Situation Reports. Retrieved from https://www.who.int/emergencies/diseases/novel-coronavirus2019/situation-reports 